\title{
Islamophobic Discourse of Czech Politicians and Political Parties on Twitter during the 2015 Migration Crisis
}

\author{
Zbyněk Vallo, Robert Jaworek, and Vladimír Matlach \\ Palacký University Olomouc
}

\begin{abstract}
This article focuses on the manifestations of Islamophobia of Czech politicians and political parties on the social networking service Twitter during the 2015 migration crisis. It utilizes the securitization theory of Copenhagen school as a theoretical framework, and through content analysis of relevant tweets aims to provide more data on what role Islamophobia played in the securitization of incoming migrants. We find that although securitization, and much more politicization, of migrants took place, obvious Islamophobia, similar to the one of the Czech Islamophobic movement, happened only in some cases. A number of those politicians who politicized or migrants and Islam usually raised their voices against radical Islamophobes.
\end{abstract}

\section{Keywords}

Islamophobia; migration crisis; Czech politics; Twitter; securitization theory; securitization

\section{Introduction}

In recent years, there have been several articles dealing with the issue of Islamophobia in Eastern Europe (Lewicki 2018; Bobako 2018; Sayyid 2018). This article further explores the issue of Islamophobia in Eastern Europe, particularly on the Czech political scene during the 2015 migration crisis which the European Union (EU) had to deal with. The Czech Islamophobic movement emerged during this migration crisis and had a considerable impact on public debate, being viewed as a representative viewpoint of Czech society, most of which rejected the idea of accepting Muslim refugees (Slačálek, Svobodová 2018, 479-480). We explore Islamophobic expressions of main Czech political actors on Twitter social networking service. Our

\footnotetext{
* Zbyněk Vallo (corresponding author), Department of Politics and European Studies, Faculty of Arts, Palacký University Olomouc, Křížkovského 12, 77180 Olomouc, Czech Republic; zbynek.vallo01@ upol.cz; ORCID: 0000-0003-3338-9895; Robert Jaworek, Department of General Linguistics, Faculty of Arts, Palacký University Olomouc, Křížkovského 14, 77180 Olomouc, Czech Republic; robert.jaworek01@upol.cz; ORCID: 0000-0001-6419-640X; Vladimír Matlach, Department of General Linguistics, Faculty of Arts, Palacký University Olomouc, Kř́žzovského 14, 77180 Olomouc, Czech Republic; vladimir.matlach@upol.cz; ORCID: 0000-0002-4111-7382.
} 
article utilizes the analytical framework of securitization theory. According to Arend Lijphart's typology of case studies, this article is an interpretative case study (Lijphart 1971, 691-2). Thierry Balzacq identifies four main methods that can be used for securitization analysis (either separately or in combination): discourse analysis, ethnographic research, process-tracing, and content analysis (Balzacq 2011, 31, 38). In our article, we apply securitization theory through content analyses of various relevant downloaded tweets. We then discuss what impact the results of our research have on the overall understanding of the Islamophobic discourse in the Czech Republic.

The securitization theory helps to find out what differentiates security and the process of securitization from a political one. To do that, strict criteria have to be met in order for threats to become security issues: they have to be staged as existential threats to a referent object by a securitizing actor, who thus generates consent with emergency measures ${ }^{2}$ beyond rules that would be otherwise binding (Buzan, Waever, de Wilde 1998, 5). We base our research questions (RQs) on this theoretical ground and by answering them, we want to find out if the securitization of migrants and refugees was actually based on framing of these people as a security threat because of a societal reason, that is, their assumed religion-Islam. Moreover, securitization is a theory that works well with quantitative research (Fox, Akbaba 2015, 175).

RQ1: What was mainly presented as an existential threat?

RQ2: What were the main referent objects of securitization?

RQ3: Which of the examined subjects of analysis were securitization actors on Twitter?

RQ4: Which of the subjects of our analysis significantly politicized the issue of migration?

For the purpose of our research, we have selected 66 Twitter accounts belonging to relevant Czech political actors, mostly politicians and political parties, and also the Islamophobic movement "We Don't Want Islam in

2 The authors of securitization theory also use terms extraordinary measures and extraordinary means (Buzan, Waever, de Wilde 1998, 21, 24). 
the Czech Republic" (Islám v České republice nechceme_IVCRN). ${ }^{3}$ Our choice was limited by the number of people who had Twitter accounts in the time of the migrant crisis. We downloaded tweets published on these accounts during the period from April 1, 2015, to December 31, 2015, using Twitter's premium API and Python programing language. Subsequently, the raw data was divided into two datasets based on these criteria: (a) text of the tweet contained at least one of our predefined keywords $s^{4}$ related to the migration crisis, (b) text of the tweet contained at least one of the following hashtags: \#EU (248 occurrences), \#imigrace (75 occurrences), \#migrace (59 occurrences), \#V4 (42 occurrences). These hashtags were selected based on the analysis of most frequent hashtags relevant to the migration crisis among downloaded tweets. Both datasets were sorted based on the tweet's authors and were converted to.csv format where each tweet had attributes: tweet's ID, date of publication, author's nickname, text, and found keyword(s). Subsequently, primary qualitative analysis was carried out on .csv tables to find out whether

3 1PavelSvoboda (Pavel Svoboda), AdamUsvit (Petr Adam), AndrejBabis (Andrej Babiš), buriansedlcany (Jiří Burian), CernochUsvit (Marek Černoch), CSSD (ČSSD, i.e. Czech Social Democratic Party), czKSCM (KSČM, i.e. Communist Party of Bohemia and Moravia), DanielDherman (Daniel Herman), Dolejssiri (Jiří Dolejš), EvzenTosenovsky (Evžen Tošenovský), hasek_michal (Michal Hašek), HnykovaUsvit (Jana Hnyková), HolikJSPD (Jaroslav Holík), honzabartosek (Jan Bartošek), charanzova (Dita Charanzová), ivcrn (IVČRN), JezekCZ (Petr Ježek), jhamacek (Jan Hamáček), jirivosecky (Jiří Vosecký), Kadnerusvit (David Kádner), kalousekm (Miroslav Kalousek), kducsl (KDU-ČSL, i.e. Christian and Democratic Union-Czechoslovak People's Party), kolovratnikm (Martin Kolovratník), Konecna_K (Kateřina Konečná), KorunaCeska (Koruna Česká), LankRealiste (Martin Lank), LudekNie (Luděk Niedermayer), Ma_Novotny (Martin Novotný), market_a (Markéta Adamová), MartinPutna (Martin Putna), mased101 (Martin Sedlář), Mdlabajova (Martina Dlabajová), MichKucera (Michal Kučera), Milan_Chovanec (Milan Chovanec), MJureka (Marian Jurečka), msojdrova (Michaela Šojdrová), ODScz (ODS, i.e. Civic Democratic Party), OlgaSehnalova (Olga Sehnalová), P_Fiala (Petr Fiala), PavelBelobradek (Pavel Bělobrádek), pavelpoc (Pavel Poc), PetrKudela1 (Petr Kudela), PetrMachMEP (Petr Mach), PiratskaStrana (Pirátská strana, i.e. Czech Pirate Party), PocheMEP (Miroslav Poche), Pospisil_Jiri (Jiří Pospíšil), PREZIDENTmluvci (Jiř́i Ovčáček), RadimFialacz (Radim Fiala), sněmovna (Chamber of Deputies of the Parliament of the Czech Republic), STANcz (STAN, i.e. Mayors and Independents), strakovka (Government of the Czech Republic), stropnickym (Martin Stropnický), svobodni (Svobodní, i.e. Freedomites), Telicka (Pavel Telička), tomio_cz (Tomio Okamura), TomZdechovsky (TomášZZdechovský), TOP09 (TOP 09), Vaclav_Hampl (Václav Hampl), VaclavLaska (Václav Láska), VaclavZemek (Václav Zemek), VeraJourova (Věra Jourová), ZahradilJan (Jan Zahradil), ZaoralekL (Lubomír Zaorálek), Zbynek_Stanjura (Zbyněk Stanjura), zeleni_cz (Zelení, i.e. Green Party), zenisek_m (Marek Ženíšek).

4 Islám (Islam), islamismus (Islamism), muslimové (Muslims), migranti (migrants), terorismus (terrorism), schengen (Schengen), invaze (invasion), civilizace (civilization), kultura (culture), džungle (jungle), v4 (V4, i.e. The Visegrad Group), visegrád (The Visegrad Group), Merkelová (Merkel, i.e. Angela Merkel), pegida (Pegida), afd (AfD, i.e. Alternative for Germany), ateismus (atheism), sekularismus (secularism), sekulární (secular), hodnoty (values), křestanství (Christianity), peníze (money), neziskovky (NPOs, i.e. nonprofit organizations), soros (Soros, i.e. George Soros), sluníčkáŕi, arabové (Arabs), afričani (Africans), džihád (jihad), brusel (Brussels), eu (EU, i.e. European Union), rasa (race), novináŕi (journalists), média (media), šabatová (Šabatová, i.e. Anna Šabatová), šátky (scarves), konvička (Konvička, i.e. Martin Konvička), hampl (Hampl, i.e. Petr Hampl), ivčrn (IVČRN, i.e. We Don't Want Islam in the Czech Republic), Okamura (Okamura, i.e. Tomio Okamura), bpi (BPI, i.e. ), havel (Havel, i.e. Václav Havel), liberalismus (liberalism), liberální (liberal). 
these tweets mentioned any existential threats and its reference objects, or if they contained any politicization. In order not to exceed the number of tweets we can download, we limited the number of keywords we searched for. Also, not all of the searched Twitter accounts contained the keywords we were looking for.

The highest amount of people arrived in Europe between April and December of 2015. The amount of arrivals dropped significantly from April 2016 (UNHCR 2020). On March 20, 2016, the EU-Turkey migration deal entered into force (BBC 2016). After that, the number of arriving people remained low. Because of the limited number of tweets that we could download, we decided to focus on the period between April and December of 2015. Works of other researchers, namely Miroslav Mareš and Přemysl Rosůlek, and also Islamophobia Report 2015, helped us to determine relevant political actors for our analysis and offered the opportunity to compare our results with other research about Islamophobia in Czech political discourse during the migration crisis (Mareš 2015; Rosůlek 2017; Dizdarevič 2015, 115-130).

Multiple studies were focusing on Islamophobia in the Czech Republic, but not all of them were embedded in a theoretical framework (Rosůlek 2017, 22). Among the exceptions are works of Strapáčová and Hloušek, who dealt with the way the Czech extremist politicians used to frame the issues related to Muslim migration, Slačálek and Svobodová, studying the ideology of the Czech Islamophobic movement, and Vendula Prokůpková, who examines the mobilization waves of the Czech anti-Islam movement. They utilize various theories for their works (Strapáčová, Hloušek 2018; Slačálek, Svobodová 2018; Prokůpková 2019). ${ }^{5}$ There is also a study of attitudes of (among others) Czech people toward Muslim refugees conducted by Bruneau, Kteily, and Laustsen, showing effects of dehumanization on attitudes toward Muslim refugees during the 2015-2016 crisis (Bruneau, Kteily and Laustsen 2017). Karel Černý explores the similarities between modern-day Islamophobia in Czechia and historical pre-World War Two anti-Semitism (Černý 2017). We compare our results with the findings of these authors. For this study, we have decided to use the securitization theory of the Copenhagen school, which has been already used by Zvada for his qualitative study of Islamophobic rhetoric during the Slovak parliamentary elections (Zvada 2018). It may offer an opportunity to compare Czech and Slovak Islamophobic tendencies in politics within the same theoretical framework and allow more comparative

5 For other Eastern European countries, see, for example, the study from Monika Bobako, who explores diversity of anti-Muslim discourses in Poland (2018). 
research in the field of Islamophobia in Central Eastern Europe ${ }^{6}$ (Zvada 2018, 220; Lijphart 1971, 691). Linguistic analysis can identify relevant samples of discourse for further analysis (Vuori 2011, 187). We also want to provide more data for the discussion of Islamophobia in Eastern Europe. One reason for that is Brubaker's distinction between populisms of Northern and Western Europe (liberal and Christianist) and of East-Central Europe (nationalist, anti-liberal), connecting both with Islamophobic tendencies, which puts the Czech Republic into the Eastern group of countries with Poland, Hungary, and others (Brubaker 2017, 1193-4, 1206, 1208, 1210). In contrast, Slačálek and Svobodová indicate that the Czech Islamophobic movement shows similarities with Northern and Western European populism, presenting liberal values as a referent object (Slačálek, Svobodová 2018, 494-5). We hope that our data will shed light on this problem as well. We also want to compare our research with other research of securitization of Islam and Islamophobia. ${ }^{7}$

\section{Securitization Theory, Islamophobia, and Twitter}

Securitization is created intersubjectively and can be studied directly, without the need for indicators - by studying discourse and political constellations. The securitizing discourse is not successful securitization; yet, it is only a securitizing move. The audience has to accept it for us to be able to call it successful. Thus, analysts must understand the process of constructing a shared understanding of threat. The process of securitization is what in language theory is called a speech act (the utterance itself) (Buzan, Waever, de Wilde 1998, 23-6). Any public issue can be located at spectrum ranging from nonpoliticized (it is not part of public debate and does not require the attention of the state), politicized (it is part of public debate and requires allocation of state resources) and securitized (Ibid, 23-4). Securitization may include a number of practices, not only speech, but also changes in mainstream policies or bureaucracies (Cesari 2012, 433). Matt McDonald also points out that a form of act constructing security is defined too narrowly (speech of dominant actors, usually political leaders), while excluding images and material practices (McDonald 2008, 564). We bare this criticism in mind, but analysis of Twitter inherently excludes the study of material practices. We do not work with images either, as our dataset contains very few images, and analyzing the photos contained in some of the articles to which tweets link is beyond the scope of this work. We also do not study through which media was the

6 For other examples of securitization of migrants in Slovakia, see works of Androvičová, and Žúborová and Borárosová (Androvičová 2015; Žúborová, Borárosová 2017). For securitization of migration in Eastern Europe see Lalić, Ćeranić 2019 (Lalić, Ćeranić 2019).

7 For example works of Kaya and Cesari (Kaya 2009; Cesari 2012). 
securitization and politicization done, as most politicians who shared links to media outlets on Twitter simply shared what they stated when they were asked about the issue of migration by particular media outlet in an interview or when they participated in a TV discussion. In our work, we are interested in the uttered securitizing and politicizing moves, as these should help us understand who from the political elites spreads Islamophobia.

Tkaczyk, in his analysis of coverage of the migration crisis in Czech online media, codes as politicization problems such as administrative issues, protests, and demonstrations, to which the recommended solutions are relocation quotas, policy changes, or integration programs. Any problem, which is more serious (criminality, security risk) and recommended solution, which is beyond otherwise binding rules (border controls, deployment of military forces, etc.) is coded as securitization (Tkaczyk 2017, 104). Every speech act has its facilitating conditions, among them contextual and social. It is necessary to hold the position from which the act can be made and to follow the security form and construct a plot that includes existential threat, a point of no return, and a possible way out. Particular "dialects" of the different sectors have to be added (such as talking identity in the societal sector). The securitizing actor has to be in a position of (not necessarily official) authority and the threat has to be actually held as threatening (tanks on borders, for instance) (Buzan, Waever, de Wilde 1998, 31-3).

Migration is seen by $63 \%$ of Czech people as one of the main problems of the EU. The second biggest one is terrorism (47\%) (ČTK 2017). Hence, we assume that the threat of migration can be held as threatening. Regarding the distinction between securitization and politicization, we proceed in a same way as Tkaczyk and if we do not see a threat in tweet as existentially threatening and/or the actor asking for extraordinary measures, we code it as politicization. There are some threats that are threatening, but not existentially, for example threat of increased spending of money. We code neither these nor mere mentioning of the keyword as politicization. We exclude tweets like 3941 when the Czech Social Democratic Party (Česká strana sociálně demokratická, $\check{C} S S D$ ) mentions participation in a debate about various topics in the Václav Havel club in Brussels, without specifying what was said and what is the stance of the party on these issues. We also do not code de-escalation of heated political debates as politicization, because it goes against securitization and politicization of the topic and thus it does not tell us anything about the focus of our study-Islamophobia. In cases like that of Pavel Svoboda, we pay attention to the fact that he stood against extremist views and criticized 
extremists such as Tomio Okamura and Martin Konvička, which we code as politicization (he kept the issue political, but did not securitize it).

Almost all of the IVCRN tweets are at least loosely connected with Islam or migration, but only some are "political" or have any political message connected to the migration crisis. These were coded as politicization or securitization, respectively. The rest of them (for example, tweets about Muslims and dogs) were not coded either as politicization or securitizationthey may be anecdotal, spread hate (and in many cases they do), but are rather apolitical and not clearly connected with security. Furthermore, lots of the IVCRN tweets have links to the deleted Facebook page of IVCRN ${ }^{8}$ and the tweet with the link usually ends before we can determine what was the content of the, now lost, message. This is a case for some tweets from other accounts too. IVCRN also serves the purpose of controlling our results, as we are sure that it is Islamophobic movement and thus we can compare the quantity and content of securitization of other actors with IVCRN, which gives us a better picture of whether other actors used Islamophobia in their securitizing moves. According to Thierry Balzacq, securitization is a sustained strategic (pragmatic) practice, which is part of a configuration of circumstances-context, psychocultural disposition of audience, and the power the speaker and listener bring to the interaction, in which the securitizing actor uses discursive techniques to persuade the audience. Such techniques include the use of metaphors, emotions, stereotypes, gestures, silence, and lies (Balzacq 2005, 172-3). The context of the whole migration crisis helps us to understand which tweets to be coded as securitization or politicization. Tweets are in many cases really short and only by putting them into the context of other tweets and comments to the original tweet, as well as the context of the situation in which they were written, we can understand what the message was. Regarding the context, it is also worth noting that during the 2015 migration crisis, three main Czech online media outlets politicized the crisis and, referring to possibilities of Islamization and terrorism, presented it to a great extent as a security threat (Tkaczyk 2017, 91, 107). Two main television broadcasters also stressed mainly security and administrative aspects of the crisis in their TV news (Tkaczyk, Pospěch, Macek 2015, 6). In fact, there was a blatant dehumanization of refugees in Czechia during the migration crisis (Bruneau, Kteily, Laustsen 2017). Works of other authors also provide a context for us, as we can better understand positions of various political actors by comparing our results with the findings of other scholars.

8 IVCRN's main Facebook page was deleted in 2016 due to spread of hate content (Šlerka, Fiala 2018, 237). 
The possibility for successful securitization will also vary dramatically with the position held by the actor (Buzan, Waever, de Wilde 1998, 31). Media agenda of two main Czech TV news relied heavily on the expressions of political representatives (Tkaczyk, Pospěch, Macek 2015, 6). These are the reasons for choosing to focus on elected politicians and relevant political parties, as they are the ones who hold the positions of authority, and on Islamophobic movement, IVCRN, which was, as mentioned above, viewed as representing the majority opinion in Czech society.

In the content analysis, the meaning of the text is fixed and if coded well, it can be extracted and replicated by other researchers. Differences in research results of various analysts then show that there may be a problem in the analysis. Both qualitative and quantitative research methods can be applied in content analysis. A qualitative research method can be used if the investigator looks for the presence or absence of securitization' (Balzacq 2011, 51).

Referent objects in societal sector of security will be large-scale collective identities that can operate independently of the state, for example religion or nation (Buzan, Waever, de Wilde 1998, 22-3). Threats to identity are threatening some "we" and also contribute to the construction and reproduction of "us" (Ibid, 119-120). This "we" has to be threatened on its identity (Ibid, 123). Thus, if we can see threats based on identity, we can assume that societal reasons, not economic or political, are in play. Regarding security policies made in defense of religion, faith (religion) is a particularly strong referent object and therefore easily securitized because it is already existential. Any challenges are easily seen as threats. Furthermore, religiously based securitizations have a special inclination to violence because of the logic of a cosmic war ${ }^{10}$ (Lausten, Waever 2000, 739). We assume that securitization based on religion means that Islamophobia is present.

According to Ayhan Kaya, the issue of the illegal migration has been picked up by Western political elite and state administrations as the source of problems such as unemployment, violence, terror, and other social and cultural troubles. This then shapes public perception of migrants. Illegal immigration is presented as external force, rooted in regional disorder, from which the EU can protect Europe's inhabitants. There is no mentioning of complex colonial and post-colonial histories in this discourse. Kaya also states that anti-illegal migration activity implies discourses of identity, inclusion, and exclusion. Illegal migrants and refugees are all the same and presented

9 For examples of content analysis, see chapters 4 and 6 (Vultee 2011; Salter 2011).

10 Cosmic war is an idea of a great encounter between cosmic forces of ultimate good and evil, divine truth and falsehood. It grants sacred legitimacy to worldly causes (Laustsen, Waever 2000, 724). 
in a negative way (Kaya 2009, 9-10). Indeed, even in the Czech Republic, this is the case, as Islamophobia seems to be a product of peoples' perception of international events (like the so-called War on Terrorism), rather than a product of everyday interaction with largely integrated Czech Muslims (Černý 2017, 399). States utilize discourse of securitization as a form of governmentality designed to unite a society politically by drawing an existential threat in the form of an internal or an external enemy. Migrants are often presented as enemies that undermine the national culture, steal the nation's resources and jobs, and bring in alien religions (Kaya 2009, 201-2). Main topics of the Czech Islamophobic discourse include (among others) issues of threats to the security, and incompatibility with European society in religious, cultural, and other respects (Černý 2017, 399).

Securitization of Islam specifically involves actors who consider Islam as an existential threat to European and secular norms and, therefore, justify extraordinary measures to control and contain it. Historically, "Homo Islamicus" is the typical other of Western modernity. Anti-Islamic discourse is then the most obvious feature of securitization of Islam, ranging from portraying Islam as a danger to Christian society to associations of Islam with terrorism. We can also see other trends, for example, distinction between "good" and "bad" Islam, as well as a rise of Muslims criticizing their own communities (Cesari 2012, 433-6).

In securitization theory, there are functional actors as well. They affect the dynamics of a given sector, without being securitizing actors or referent objects (Buzan, Waever, de Wilde 1998, 35-6). Our functional actor is the Twitter social networking service, with its set rules, terms of use, and the way it works. Tweeting in itself is an emergent site of discourse (Downing 2019, 8). Underlying algorithmic structures mediate communication flows between actors. This then interacts with the discourse in play. Unlike on Facebook, where friendship request is required for the platform to allow you to follow somebody, Twitter is very open. Anyone can be followed and tweets can appear in your feed, without the need to be followed back (Warrington 2017, 267). Twitter, because it has quite a limit on how many signs can user write in one post, is also best used for sharing short news updates, opinions, and links that alert users about news, articles, and webpages that provide more information (Rasmussen 2015, 201). Twitter is a highly political platformthere are lots of political and civil society activists active on it. They inform other users about political issues, and mobilize and engage them. They also generate added attention to specific, often political, topics and issues. Hashtags allow actors to connect their actions to a broader campaign or 
issue. They also bridge the process of speech production and the situation of speech reception. But hashtags can also change meaning in time and place (Downing 2019, 8). For us, hashtags are a representation of how much was a particular issue important in the society in a given time-was Islamophobia the most important issue discussed on Czech twitter or did other topics get bigger traction?

\section{Analysis of Islamophobia on Czech Twitter}

We conducted a content analysis of the sum of all tweets. We were looking for existential threats (existenčni hrozba) and referent objects (referenční objekt). We tried to generalize existential threats and referent objects as much as possible-without compromising the original message, but at the same time to allow any generalization of the results. Sometimes the tweets mention the keywords (klícová slova) but do not mention them in a way that would constitute securitization. This is coded as politicization (Politizace). ${ }^{11}$ The results of our analysis are as follows (numbers of mentions of existential threats and referent objects, as well as numbers of securitizing moves and politicizing moves, are in brackets):

RQ1: What was mainly presented as an existential threat?

Things most often presented as existential threats were (see Table 1): Muslims (11), Islam (11), migration (6), terrorism (6), ISIL (4), invasion of Muslims (4), migrants (4), Islamic migrants (2), Muslim terrorists (1). All other existential threats were mentioned only once or twice. They ranged from criminality to

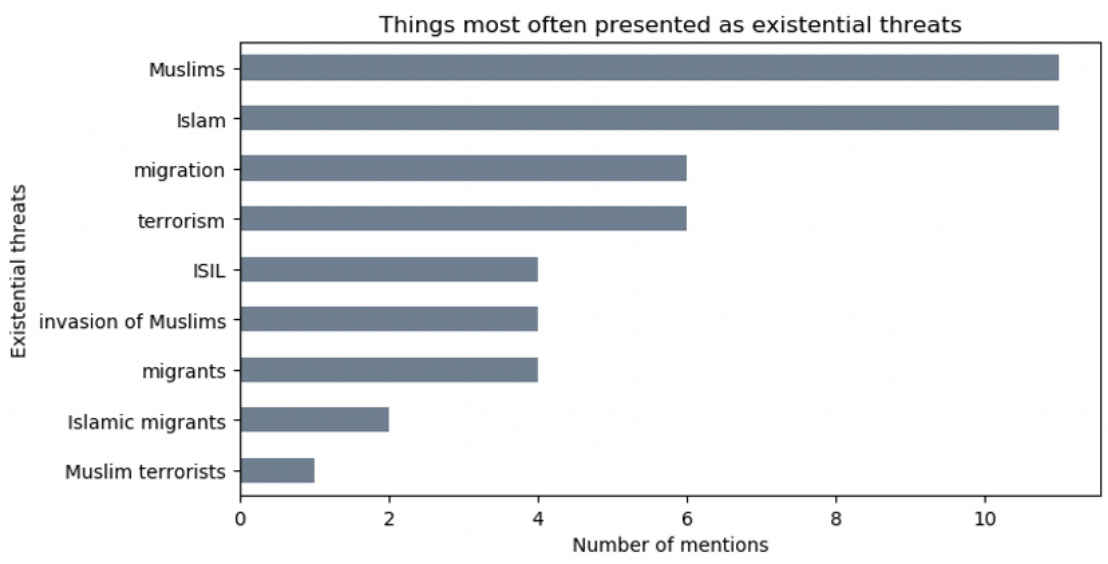

Table 1

diseases. 
RQ2: What were the main referent objects of securitization?

The main referent objects of securitization were (see Table 2): security (21), Europe (9), freedom (9), EU (7), and democracy (5).

RQ3: Which of the examined subjects of analysis were securitization actors on Twitter?

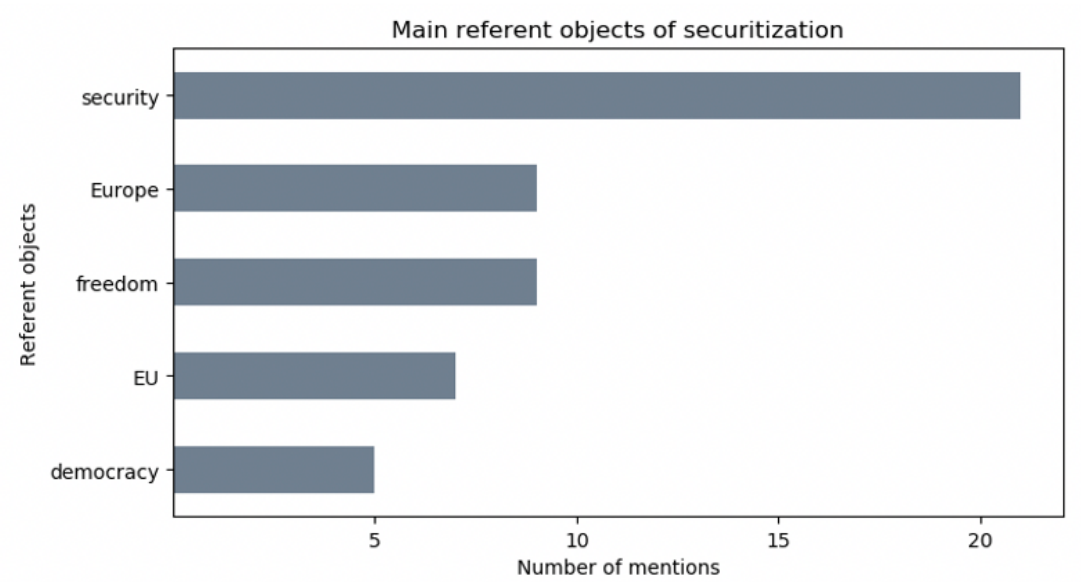

Table 2

IVCRN (29), Jiří Dolejš (10), Pavel Svoboda (7), Radim Fiala (6), Marek Černoch (3), Tomio Okamura (2), Marian Jurečka (2), Jaroslav Holík (1), KDU-ČSL (1), Kateřina Konečná (1), Občanská demokratická strana (ODS) (1), Pavel Bělobrádek (1), Miroslav Poche (1), and Jiří Pospíšil (1). We can say that no one securitized the issue of migration as much as the IVCRN (see Table 3).

RQ4: Which of the subjects of our analysis significantly politicized the issue of migration?

IVCRN (44), Petr Ježek (34), Jiří Dolejš (22), Tomáš Zdechovský (16), Jiří Pospiśsil (15), Pavel Telička (14), Pavel Bělobrádek (12), ODS (12), the government (12), Pavel Svoboda (10), Lubomír Zaorálek, the Minister of Foreign Affairs (7), and the Party of Free Citizens (6) (see Table 4).

Regarding the main political parties and politicians who held positions of power and authority, and institutions, the results were as follows (some of them were mentioned above, shown again for comparison):

The government (12), ODS (12, as well as 1 securitizing move), Lubomír Zaorálek, the Minister of Foreign Affairs (7), Party of Free Citizens (6), ANO (6), ČSSD (4), KSČM (4), The President (4), Milan Chovanec, the Minister 


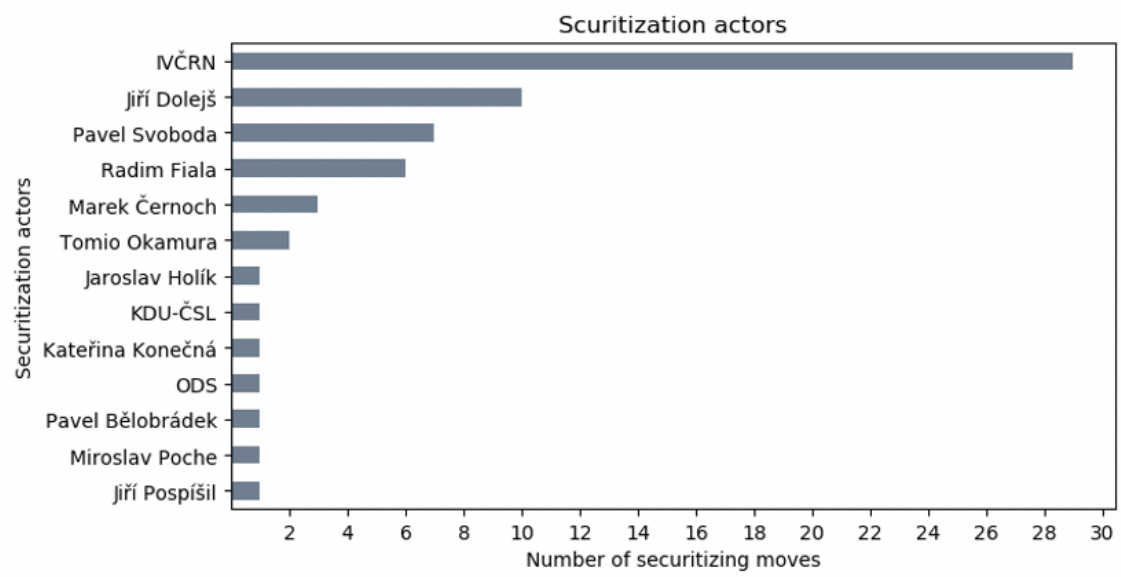

Table 3

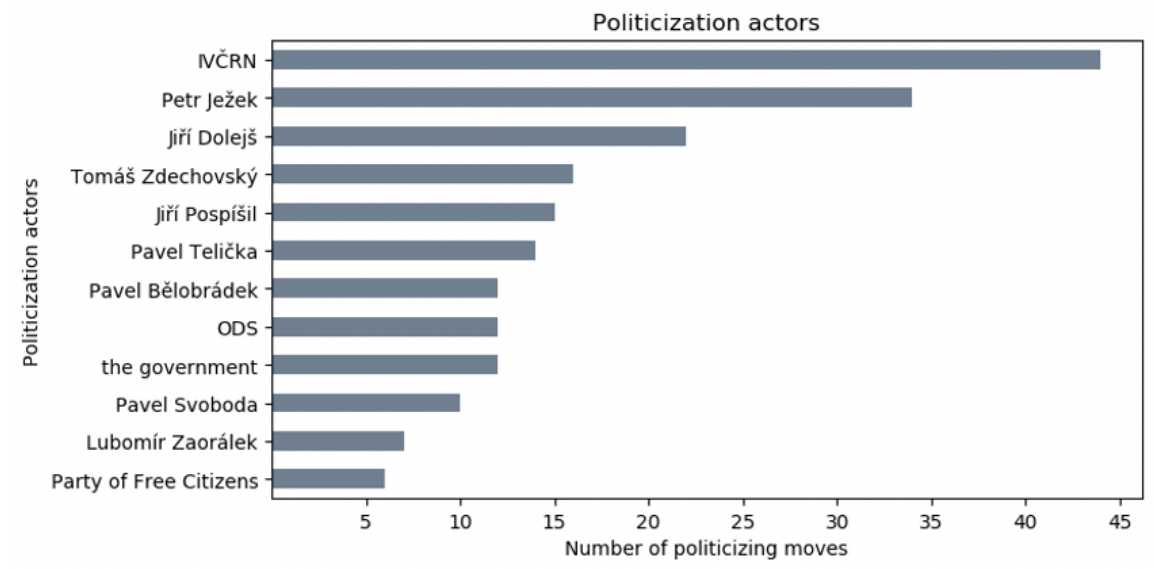

Table 4

of Interior (4), Verra Jourová, The Commissioner for Justice, Consumers and Gender Equality (4), KDU-ČSL (1, as well as 1 securitizing move), The Chamber of Deputies (1), STAN (1), Pirates party (0), Green Party (0), and TOP 09 (0).

Regarding the first RQ, we see a high number of mentions of Muslims, Islam, terrorism, migration, and migrants as threats. Thus, we can say that Islam and Muslims were presented as a threat. The answer to the second RQ is more surprising. We do not see culture or identity being primarily endangered. What is mainly endangered is the security of people. Europe, which may be understood as identity reference (and in many securitizing tweets it was 
presented in this way), is present in the second place. Other most endangered things are freedom, EU, and democracy, which are rather political objects, although it is debatable if the EU is a substitute for Europe and understood in an identitarian way and whether freedom is a political entity or expression of identity. The tweets did not constitute a clear view on the matter.

Answering the third and fourth RQs properly, we have to discuss the securitizing moves further, as some of the politicians securitized the issue of migration, yet raised their voices against populists and extremists at the same time. The same goes for politicization. This section is structured by parties, beginning with the government parties and continuing with the strongest opposition ones. All relevant Twitter accounts for a particular party are discussed in the same paragraph (official Twitter account, accounts of members of the Parliament (MPs) and European Parliament (MEPs)).

Regarding the main government party, the Czech Social Democratic Party (Česká strana sociálně demokratická, ČSSD), we found mostly insignificant politicization and in the case of MEP Pavel Poc also an expression of solidarity with refugees in one tweet. In contrast with that, MEP Miroslav Poche securitized the issue of terrorism once and politicized migration on several occasions. Lubomír Zaorálek, the Minister of Foreign Affairs, politicized the issue of migration more significantly, as did the Minister of Interior Milan Chovanec. Strong politicization can be also seen in the official Twitter account of the government, which was then run by Bohuslav Sobotka from ČSSD.

An MEP Petr Ježek (ANO/ALDE) significantly politicized the issue of migration, but only to raise the issue on agenda. His politicization was not a populist one. Pavel Telička (ANO/ALDE) politicized the issue of migration too. Dita Charanzová, on the other hand, did not securitize or politicize the issue (we found only one politicization in her tweets). Martin Stropnický politicized the issue, but the number of relevant tweets downloaded from him was not significant enough to draw any conclusions. We found in our analysis that $\mathrm{ANO}$ was one of the parties that rather politicized the issue of migration, however not significantly.

As for the last party of the coalition, Czech Christian Democratic PartyKřestanská a demokratická unie-Československá strana lidová, KDU-ČSL, its MEP Pavel Svoboda (KDU/EPP) retweeted information about thousands of migrants coming to Europe, which, in the context of the rest of the tweets, may support securitization. He also politicized the issue of migrants based on religion. On the other hand, he stood in opposition to extremists and some of his tweets contain sentences about Tomio Okamura and Martin Konvička with nuanced, yet derogative, connotations about these two extremist 
politicians. Tomáš Zdechovský (KDU/EPP) politicized the issue of migration significantly as well. Pavel Bělobrádek (KDU) politicized migration on 12 occasions and securitized Islam once, yet he raised his voice against populists.

Communist politician Jiř́ Dolejš (Communist Party of Czechia and Moravia, Komunistická strana Čech a Moravy, KSČM) significantly deescalated the political situation in his tweets. He supported moderate Muslims and was against the PEGIDA movement, ${ }^{12}$ fascism, IVCRN, bigotry, etc. He was afraid of the rise of fascism in Czechia and Europe broadly. Many of his securitizing tweets also identify the radical right, not Muslims, as an existential threat. The Czech Communist Party politicized the issue of migration, but, for example, Zuzka Bebarová-Rujbrová deescalated the securitization significantly, making the issues of migration and terrorism politicized. On the other hand, she argued against securitization and against going beyond the normal binding rules in politics and against new extraordinary measures (see URL in tweet 4283). Other communist politicians also argued for solving the issue of migration through normal political processes (as seen in multiple tweets).

The members of the TOP09 Party usually stood against populists or tweeted too little about the topic to draw conclusions from their tweets. One exception is Jiří Pospíśil (TOP09/EPP), who was clearly against accepting refugees. At one occasion, he even securitized the refugee quotas as an existential threat. This lies in striking contrast with the rest of his party.

Civic Democratic Party (ODS) on its official Twitter account not only politicized but also securitized the issue of migration when it presented refugees as an existential threat to EU borders. However, we did not find any significant securitization or politicization from its members on Twitter. On the Twitter account of Petr Fiala, the leader of Civic Democrats, we did not find any significant politicization or securitization.

Three populist politicians from the Dawn of Direct Democracy (Úsvit prímé demokracie), i.e. Marek Černoch, Radim Fiala, and Tomio Okamura, show interesting results in our analysis. There were eight Twitter accounts of politicians from this party analyzed in our research. Most of them simply did not tweet much, so we have not obtained enough data from their accounts. Marek Černoch is one of those who politicized the issue of refugee quotas and who securitized the migration and Islam on three occasions. Radim Fiala securitized frequently with respect to the other members of this party. Okamura did not securitize significantly on Twitter.

12 PEGIDA is right-wing populist street movement (Dostal 2015, 523). 
The analysis of hashtags helps us to put our findings into context with the rest of the political topics that played an important role during the examined period. We have three tables with 10 and 20 most frequently used hashtags. We have separated the Czech hashtags (used in Czech language tweets only) from the rest of the hashtags (see Table 5, purple), and then put all hashtags together (Table 6, blue). Both tables show us that the issue of migration was not the most important one for the accounts' owners included in our analysis. Out of 20 most frequently used hashtags (non-Czech tweets included, Table 7), EU was the most common one (248 tweets), followed by TTIP (Transatlantic Trade and Investment Partnership, 231) and EET (Electronic evidence of sales, 121); immigration was on the 7th place (75), migration was 10th (59), and V4 - which we see as loosely related to the topic of migration-was 20th (42). ${ }^{13}$ This may be given by the fact that MEPs used Twitter more often and tweeted regularly about their agenda, as seen in our downloaded tweets.

\section{Putting the Findings into Context}

As indicated in the theoretical part, it is important to put our findings into a broader context, to fully understand them and draw conclusions from them. This section does just that and follows suit with the previous one, beginning by discussing government parties and continuing with opposition.

Milan Chovanec, as a Minister of Interior, received the biggest amount of space in TV news of two main television broadcasters. There, we were able

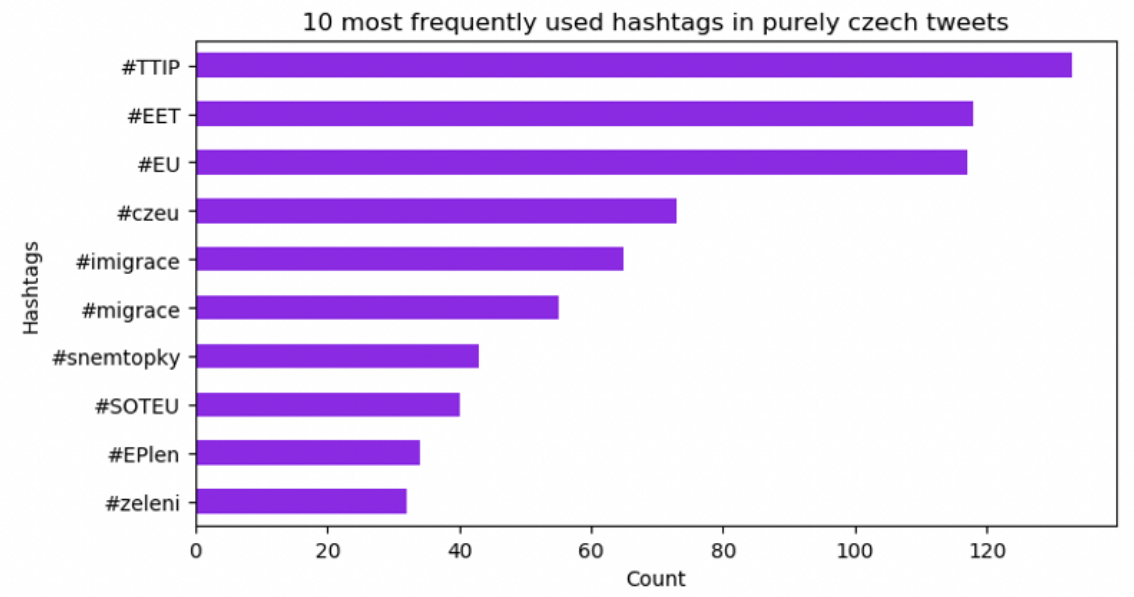

Table 5

13 See attached document "Islamophobia_30_nej". 


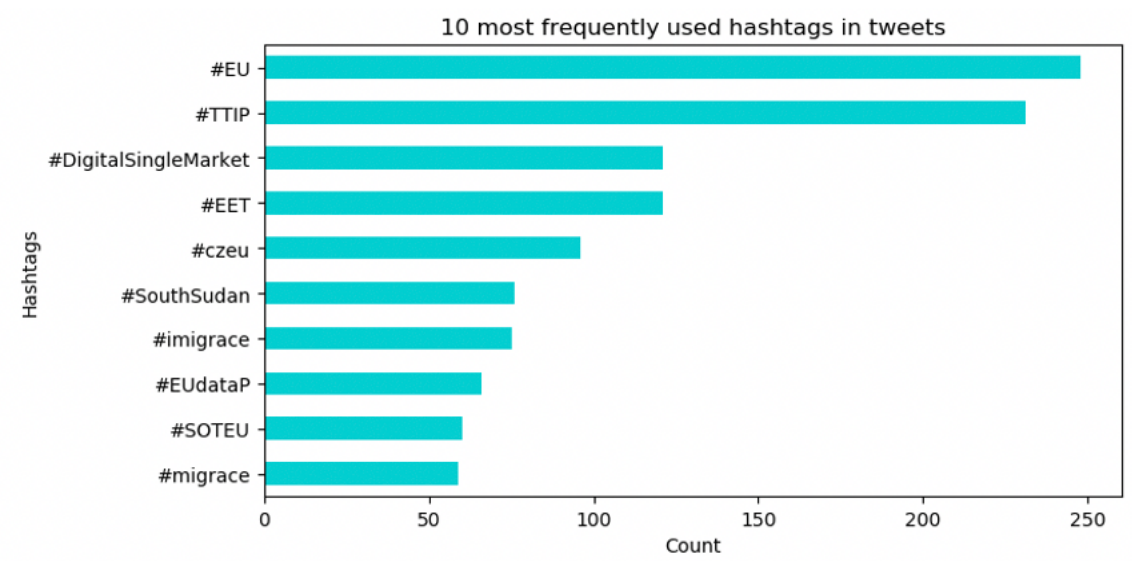

Table 6

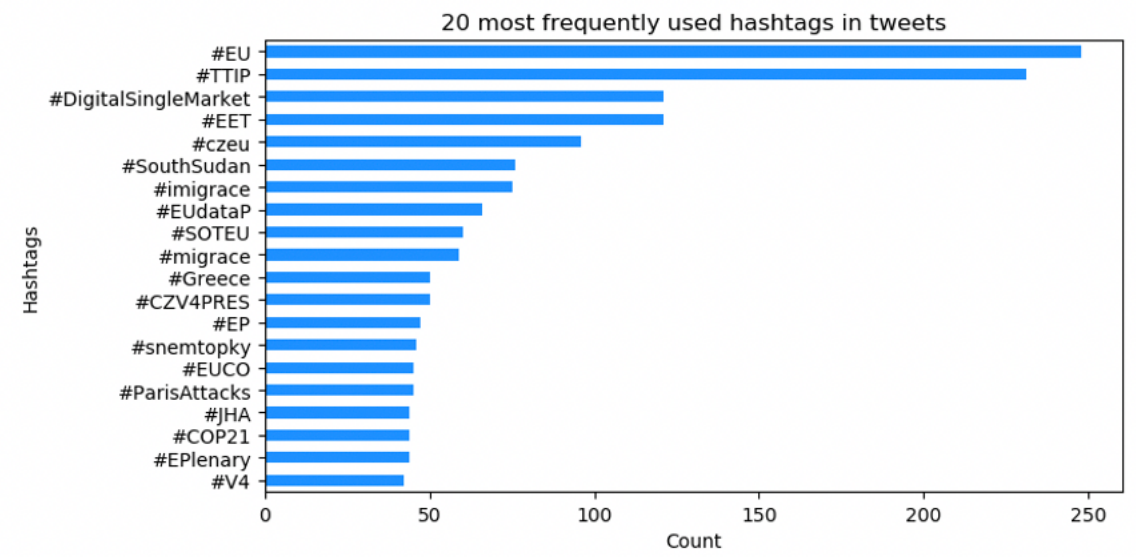

Table 7

to see framing of the migration crisis in security terms (Tkaczyk, Pospěch, Macek 2015, 6). This securitization was not reflected on Chovanec's Twitter though. The Social Democrats were the only party with elected Muslim representative, senator Hassan Mezian, who defended Islam and rejected the idea that it is a violent religion (Kopecký 2015a). The Chairman of the Chamber of Deputies from ČSSD, Jan Hamáček, publicly strongly rejected Islamophobia and stressed that Islam has an irreplaceable role in human society (Fendrych 2015). On the other hand, the regional council president from Southern Moravia region Michal Hašek from ČSSD was criticized for 
using the migration crisis for scoring easy points among voters by saying, for example, that the reality is that the Czechs do not want Islam in Czechia (Šimáček 2015b). Strapáčová and Hloušek found that there was a diversity of opinions on the migration crisis in the party. The partly exercised "soft" securitization of the migration crisis while at the same time it stressed the humanitarian aspect of the situation and the need to fight fascism and racism (Strapáčová, Hloušek 2018, 12-13). We have, on the contrary, found more politicization than securitization.

Regarding ANO party, Petr Ježek, outside of Twitter, expressed firm will to defend European values, especially freedom of speech, but at the same time he pointed out to the fact that debate in European Parliament regarding Islamic terrorism is not about Islam, but rather about terrorists and freedom of speech. The reason is that western European states are already accustomed to Muslims living there and thus there is no debate about whether Islam should be part of western societies - it already is (Denková 2015). Pavel Telička strongly raised his voice against populists. In one of the articles on his webpage, he stressed the need to combat illegal migration, but at the same time to fight xenophobia (Telička 2015). Looking back at 2015, we see that the leader of ANO, Andrej Babiš, was against the mandatory refugee resettlement quotas, but expressed an opinion that refugees could be accepted and work at those jobs that the Czechs do not want to work at (Houska 2015). On the other hand, a more coherent analysis conducted by Strapáčová and Hloušek found out that ANO was primarily securitizing the issue of migration, mentioning humanitarian aspects in a very incoherent manner. Migration is presented as an attack and migrants as a danger to European culture and civilization (Strapáčová, Hloušek 2018, 13-14). Here, we see the difference between MEPs messaging and that of Andrej Babišs, and also the limitations of the analysis of Twitter.

When we look at KDU, we can clearly see in some of Pavel Svoboda's texts published online, that he did not go as far as populists in criticizing Muslims in context of terrorism or migration, yet, he clearly expressed a preference for Christian values and determination to defend them (Svoboda 2015a; Svoboda 2015b). Bělobrádek (KDU) more clearly expressed his opinions, for example, in an interview in 2016, where he distanced himself from populists, but also expressed refusal to accept Islamic Europe (Martinek 2016). Mochtak, in his analysis of KDU-ČSL during the 2015 refugee crisis, finds such an approach as well. The party was, in the light of the migration crisis, slowly moving from positions of tolerance to a more critical stance toward migrants and Islam, rejecting multiculturalism and pushing for integration of foreigners into the system of European values. The party members were also more critical about 
Islam as a religion, which is in fundamental contradiction with Christianity (Mareš 2015, 154).

Leader of the communist party, Vojtěch Filip, criticized the EU for not doing enough to stop the migration crisis (Janouch 2015). He also called on Muslims to stand against terrorism and show the world "the true face of Islam" (ČTK 2015). Strapáčová and Hloušek find in their analysis that Czech communists implemented two main approaches toward the migration crisis: (1) securitization operationalized through strict border control and international engagement to settle the conflicts in the countries of origin of migrants, and (2) humanitarian approach with a strong emphasis on the Geneva Conventions and other humanitarian law, which should be the main basis on which to deal with refugees (Strapáčová, Hloušek 2018, 15-16).

Jiří Pospísil from TOP09 voted against the refugee quotas in European Parliament, while the rest of the TOP09 MEPs voted for accepting the quotas (Gregor 2015). The position of this party can be summarized by words of one of its then MPs Helena Langšádlová, who emphasized that it is against European values to judge people based on their religion, but that it would be wrong to close eyes in the face of long-standing migration problem in Europe (TOP09 2015). Strapáčová and Hloušek found that the party originally used very liberal rhetoric in comparison with other parties, yet was forced by the decline of its support among voters to use more of security rhetoric and "civilizationist" discourse. Despite that, the party still voiced the legal and human obligations that have to be fulfilled while dealing with refugees (Strapáčová, Hloušek 2018, 17-18).

The migration crisis resulted in an internal dispute in ODS, which was solved in April 2016 (Strapáčová, Hloušek 2018, 16). Petr Fiala in 2015 visited the Hungarian border where the Hungarian government built a fence against migrants and warned against "not-manageable onrush of refugees" (Šimáček 2015a). Jana Černochová, an ODS MP, was present in the demonstration organized by IVCRN, a move not seen entirely positively in ODS, but also an act which was not criticized by the party in any significant way (Kopecký 2015b). Senator from ODS Tomáš Grulich expressed more nuanced opinions about migration, emphasizing security and the possibility to accept refugees and migrants from Balkans and Eastern Europe (Grulich 2015). Mochtak in his analysis found that ODS saw migration as a security threat and it saw Islamist radicalism as connected to cultural and religious aspects of Islam, which was often framed as a threat or at least a source of distrust (Mareš 2015, 158). This did not manifest significantly on Twitter accounts of different 
members of the party, but the official Twitter account of ODS supports Mochtak's finding.

From January 2015 to early spring of the same year, members of the Dawn party regularly and actively participated in rallies organized by IVCRN (Prokůpková 2019, 65). Yet, Marek Černoch was very vocal against Tomio Okamura's article that called for pestering of Muslims by, for example, walking of pigs around mosques. Černoch stated that the issue at hand is too serious to be treated like this and that the party should refrain from such articles. On the other hand, the party, along with Černoch, expressed the view that the article plays down the possible threat of Islamism in Czechia (Čermáková, Bartošová 2015). Dawn party after some time split into two political parties, with Okamura leading the Freedom and Direct Democracy party (Svoboda a prímá demokracie) and Černoch staying in the Dawn party (Mareš 2015, 1312). Both were Islamophobic and can be described as a populist radical right (Mareš 2015, 144). Marek Černoch later left the party because he did not want to be associated with extremists (Kopecký 2017). Radim Fiala, on the other hand, was closely allied with the leader of the party-Tomio Okamura (Mareš 2015, 131-2). Okamura remained radical on other media platforms, dehumanizing migrants and targeting Muslims in his political statements, expressing fears that rising number of Muslims would mean the end of the Czech Republic (Strapáčová, Hloušek 2018, 19).

These information show the limits of analysis of Twitter and the need to complement the analysis by other data, which may give us a completely different picture of reality-pure counting of securitizing or politicizing moves is not enough to describe the reality. There is a strong need to understand the context and to complement our research with supplementary materials.

\section{Conclusions and Discussion}

Based on our research we can conclude that Islam and Muslims were presented as existential threats and thus securitized. The issue of migration was also hugely politicized by various political actors. The primary referent object was security. Identitarian referent object-Europe-was in the second place. It is difficult to say if the rest of the referent objects can be understood as identitarian or as political, but the results nevertheless seem to support Karel Černýs description of Islamophobic discourse in Czechia (clear association of threats with Islam, danger to security, endangered Europe, and threatened freedom). Because our referent objects include keywords such as freedom or democracy, but no mentions of nation, people, or state, we conclude that the data support findings of Slačálek and Svobodová, who, contrary 
to Brubaker, describe Czech populism as more similar to the Western and Northern European one. Repression of foreigners may be only a way of how political elites reassure certain segments of electorate about their security with concrete measures (Kaya 2009, 10). Yet, because Černý's work shows similarities between contemporary Czech Islamophobia and anti-Semitism before the Holocaust, our findings give even more urgency to the need to combat Islamophobia in Czechia.

The main securitizing actor on Czech Twitter during the 2015 migration crisis was IVCRN. The most prevalent referent object on the IVCRN Twitter account was security. Yet, we can say that many tweets from IVCRN are in line with what Kaya describes as "stigmatization of Islam" (Kaya 2009, 4-5). In response to unwillingness of elites to fulfill its demands, the movement itself evolved from a purely anti-Islamic to a broader populist movement during the 2015 migration crisis, attempting to transform its identity to one that would represent more people and become not only anti-Muslim but also anti-elite (Prokůpková 2019, 66). Based on Šlerka’s and Fiala’s findings of representation of IVCRN on Facebook, we know that the populist movement is the intersection of many different interests of various groups angry about the state of Czech society. The fulfillment of their demands regarding Islam would probably result only in the regrouping of the groups (Šlerka, Fiala 2018, 247). Thus we recommend more research about this movement to be done to determine the sources of its members' discontent.

Other significant securitizing actors were the Dawn party members. This is supported by the research of Strapáčová and Hloušek, who also find that far-right parties are using securitization more than others. President Zeman is described in their research as more populist than mainstream parties, so is ANO (Strapáčová, Hloušek 2018, 24-5). We did not find any significant politicization from President's speaker account or ANO. Another securitizing and politicizing actor was also Christian democrat Pavel Svoboda, who, on the other hand, distanced himself from radicals and populists. The same goes for other Christian democrats, as they stood against radicals, yet expressed concerns about Islam and Muslims and politicized the issue of migration significantly. Next politicizing actor was Jiří Pospíšil, who politicized (and once even securitized) more than the rest of his party members. We also find that the research on Twitter needs to be supplemented by other data drawn from public expressions of politicians and official party documents, otherwise it cannot give the researcher a full picture of reality, as seen in our analysis of members of ODS, ANO, and KSČM. It is important to mention communist politician Jiří Dolejš, who was very vocal against right-wing radicals on 
Twitter, yet politicized the issue quite a lot. The analysis of most frequently used hashtags then shows us that migration was not the main topic on Twitter accounts of Czech politicians. This is due to MEPs' nature of tweeting much more than others about their daily agenda, which included different issues than migration. Apart from IVCRN and Dawn party members, it is difficult to speak about Islamophobia on Czech Twitter as other political parties and politicians rather politicized the issue of migration. We have also rarely seen any mentions of complex historical and political problems in connection with the migration crisis; only Vojtěch Filip from the Communist Party argued in this manner, and he has done so outside of Twitter. Thus we can say that the Czech Republic resembled Western European Islamophobic discourses. But we haven't seen any trend of a dichotomy between good and bad Muslims. Yet, similarly to Western Europe, Islam was associated with danger and presented as a threat.

\section{Funding}

This work was supported by the Ministry of Education, Youth and Sports under Grants IGA_FF_2019_026 "Islamophobia and securitization of the migration crisis in the years 2014-2019: Czechia and Slovakia in the shadow of the crescent?" and IGA_FF_2019_019 "Methods of linguistic analysis in digital humanities."

\section{References}

Androvičová, Jarmila. 2015. “Sekuritizácia migrantov na Slovensku - analýza diskurzu.” [Securitization of migrants in Slovakia - analysis of discourse]. Sociológia 47 (4): 319-339.

Balzacq, Thierry. 2005. "The Three Faces of Securitization: Political Agency, Audience and Context.” European Journal of International Relations 11 (2): 171-201.

Balzacq, Thierry. 2011. "Enquiries into methods: a new framework for securitization analysis." In Securitization Theory: How security problems emerge and dissolve, edited by Thierry Balzacq, 31-53. Abingdon: Routledge.

Bobako, Monika. 2018. "Semi-peripheral Islamophobias: the political diversity of anti-Muslim discourses in Poland." Patterns of Prejudice 1-13.

Brubaker, Rogers. 2017. "Between nationalism and civilizationism: the European populist moment in comparative perspective." Ethnic and Racial Studies 40 (8): 1191-1226.

Bruneau, Emile, Nour Kteily, and Lasse Laustsen. 2017. "The unique effects of blatant dehumanization on attitudes and behavior towards Muslim refugees during the European refugee crisis across four countries." European Journal of Social Psychology, 48 (5): 645-662.

Buzan, Barry, Ole Waever, and Jaap de Wilde. 1998. Security: A New Framework for Analysis. London: Lynne Rienner Publishers, Inc. 


\section{Islamophobic discourse of Czech politicians and political parties on Twitter}

Cesari, Jocelyne. 2012. "Securitization of Islam in Europe." Die Welt des Islams, 52 (3/4): 430-449.

Čermáková, Jana, Simona Bartošová. 2015. “Okamurovy výroky o muslimech byly chybou, ř́ká poslanec Úsvitu Černoch. [Okamura's statements about Muslims were mistake, says member of parliament from Úsvit, Černoch]." iROZHLAS, January 6, 2015. https://www. irozhlas.cz/zpravy-domov/okamurovy-vyroky-o-muslimech-byly-chybou-rika-poslanecusvitu-cernoch_201501061531_sbartosova.

Černý, Karel. 2017. “Anti-Semitism Yesterday and Islamophobia Today: A Central-European Perspective." RUDN Journal of Sociology, 17 (3): 399-407.

ČTK. 2015. "KSČM: Muslimové musejí ukázat pravdivou tvář islámu." [KSČM: Muslims have to show the true face of Islam]. TÝDEN.cz. Accessed January 9, 2015. https://www. tyden.cz/rubriky/domaci/politika/kscm-muslimove-museji-ukazat-pravdivou-tvar-islamu_329577.html.

ČTK. 2017. "Průzkum: Češi za hlavní problem EU považují migraci a terrorismus." [Survey: The Czechs understand migration and terrorism as the biggest problems of EU]. $i R O Z H$ $L A S$, March 20, 2017. https://www.irozhlas.cz/zpravy-z-domova/pruzkum-cesi-za-hlavniproblem-eu-povazuji-migraci-a-terorismus_1703200648_.

Denková, Adéla. 2015. "Europoslanci: Pařížský útok EU sjednotil. Ted” musí být tvrdší k těm, kdo nectí lidské životy." [Memebers of European parliament: The Paris attack united EU. Now, it has to be tougher towards those who do not value human lives]. Euractiv, January 9, 2015. https://euractiv.cz/section/aktualne-v-eu/news/parizska-tragedie-evropu-sjednotila-ted-musi-byt-tvrdsi-vuci-tem-kdo-necti-lidske-zivoty-rikaji-europoslanci-012394/.

Dizdarevič, Selma Muhič. 2015. "Islamophobia in Czech Republic: National Report 2015." In European Islamophobia Report 2015, edited by Enes Bayrakli, Farid Hafez, 115-130. Ankara, Istanbul, Washington D.C., Cairo: SETA.

Dostal, Jörg Michael. 2015. "The Pegida Movement and German Political Culture: Is RightWing Populism Here to Stay?” The Political Quarterly 86 (4): 523-531.

Downing, Joseph. 2019. "Blurring European and Islamic values or brightening the good bad Muslim dichotomy? A critical analysis of French Muslim victims of Jihadi terror online on twitter and in Le Monde newspaper." Critical Studies on Terrorism 12 (4): 1-23.

Fendrych, Martin. 2015. "Předseda Sněmovny Hamáček odmítá starch z islámu. Učí Zemana ekonomické diplomacii." [The Chairman of the Chamber of Deputies rejects fear of Islam. He teaches Zeman how to do economical diplomacy]. Aktuálně.cz, November 2, 2015. https:/nazory.aktualne.cz/komentare/sef-snemovny-jan-hamacek-odmita-strach-z-islamuuci-zemana-e/r-fd10ca2080c211e5a80c0025900fea04/.

Fox, Jonathan, Yasemin Akbaba. 2015. "Securitization of Islam and religious discrimination: Religious minorities in Western democracies, 1990-2008." Comparative European Politics 13 (2): 175-197.

Grulich, Tomáš. 2015. "Grulich (ODS): Migrace a islám.” [Grulich (ODS): Migration and islam]. Parlemtni listy, March 16, 2015. https://www.parlamentnilisty.cz/politika/politicivolicum/Grulich-ODS-Migrace-a-islam-366537.

Gregor, Kamil. 2015 “Europoslanci hlasovali o kvótách. Nejvíce proti byli Češi.” [Members of European parliament took a vote on quotas. The Czechs were the most against]. HlidaciPes. 


\section{Journal of Nationalism, Memory \& Language Politics 14(2)}

org, September 10, 2015. https://hlidacipes.org/europoslanci-hlasovali-o-kvotach-nejviceproti-byli-cesi/.

Houska, Ondřej. 2015. "Uprchlíci by podle Babiše mohli obsadit tisíce pracovních mist, o která Češi nestojí.” [Refugees could fill thousands of job vacancies which the Czechs have no interest in]. iROZHLAS, September 12, 2015. https://www.irozhlas.cz/zpravydomov/uprchlici-by-podle-babise-mohli-obsadit-tisice-pracovnich-mist-o-ktera-cesi-nestoji-_201509120112_mhornakova.

Janouch, Roman. 2015. “Filip: EU nesmí být pasivní." [Filip: the EU cannot be passive]. Haló noviny, September 4, 2015. http://www.halonoviny.cz/articles/view/40434489.

Kaya, Ayhan. 2009. Islam, Migration and Integration: The Age of Securitization. Houndmills: Palgrave Macmillan.

Kopecký, Josef. 2015a. "Islám nemá ve svém učení násilí, ř́ká senator Mezian, lékař ze Sýrie." [Islam does not have violence in the its teachings, says senator Mezian, doctor from Syria]. iDNES.cz. Accessed March 19, 2020. https://www.idnes.cz/zpravy/domaci/islam-nema-vesvem-uceni-nasili-rika-senator-mezian-lekar-ze-syrie.A150130_132023_domaci_kop.

Kopecký, Josef. 2015b. “Žádní náckové, hají Černochová účast na protest proti islamistům.” [(There were) no nazis, Černochová defends her participation in protest against islamists]. iDNES.cz. Accessed March 19, 2020. https://www.idnes.cz/zpravy/domaci/na-hrade-jsemzadne-nacky-nevidela-haji-se-poslankyne-cernochova.A150120_141348_domaci_kop.

Kopecký, Josef. 2017. “Černoch opouští potápějící se Úsvit. Nechce být spojován s extrémisty." [Černoch leaves sinking Úsvit. He does not want to be associated with extremists]. iDNES.cz. Accessed March 19, 2020. https://www.idnes.cz/zpravy/domaci/poslaneccernoch-opousti-usvit.A170607_140402_domaci_kop.

Laustsen, Carsten Bagge, and Ole Waever. 2000. "In Defence of Religion: Sacred Reference Objects for Securitization.” Millennium: Journal of International Studies 29 (3): 705-739.

Lalić, Velibor, Predrag Ćeranić. 2019. "Securitization of migration in European Union and the role of private security firms." Security Dialogues 10 (1): 47-61.

Lewicki, Aleksandra. 2018. "Race, Islamophobia and the politics of citizenship in post-unification Germany" Patterns of Prejudice 52 (5): 496-512.

Mareš, Miroslav, Jiř́i Baroš, Pavel Dufek, Vlastimil Havlík, Michal Mochtak, Oskar Varga, Petra Vývodová, Štěpán Výborný. 2015. Ne islámu! Protiislámská politika v České republice. [No to Islam! Anti-muslim politics in the Czech Republic]. Brno: Centrum pro stadium demokracie a kultury.

Martinek, Jan. 2016. "Bělobrádek: Muslimskou Evropu nechci." [Bělobrádek: I do not want Muslim Europe]. Novinky.cz, February 13, 2016. https:/www.novinky.cz/domaci/clanek/ belobradek-muslimskou-evropu-nechci-341522.

McDonald, Matt. 2008. "Securitization and the Construction of Security." European Journal of International Relations 14 (4): 563-587.

BBC. 2016. "Migrant crisis: EU-Turkey deal comes into effect." 2016. BBC. March 20. https://www.bbc.com/news/world-europe-35854413.

UNHCR. 2020. “Operational Portal: Refugee Situations - Mediterranian Situation.“ 2020. United Nations High Commissioner for Refugees (UNHCR). March 11. https://data2.unhcr. org/en/situations/mediterranean. 


\section{Islamophobic discourse of Czech politicians and political parties on Twitter}

Prokůpková, Vendula. 2019. "Two Mobilization Waves of the Czech Anti-Islam Movement. Collective Actors and the Identity Change of the Movement 2015-2016.” Intersections. East European Journal of Society and Politics 4 (4): 51-71.

Rasmussen, Joel. 2015. "'Should each of us take over the role as watcher?' Attitudes on Twitter towards the 2014 Norwegian terror alert." Journal of Multicultural Discourses, 10 (2): 197-213.

Rosůlek, Přemysl, Veronika Hásová, Klára Jiráčková, Alexandra Kollárová, Pavla Kostková, Veronika Kramáreková, Jan Váně, Lukáš Zahradník. 2017. Sondy do studia (o) islámu v obdobi migračni krize. [Probes into the Study (of) Islam during the "Migration Crisis"]. Prague: Dokořán.

Salter, Mark B. 2011. "When securitization fails: the hard case of counter-terrorism programs." In Securitization Theory: How security problems emerge and dissolve, edited by Thierry Balzacq, 116-131. Abingdon: Routledge.

Sayyid, S. 2018. "Islamophobia and the Europeanness of the other Europe." Patterns of Prejudice 52 (5): 420-435.

Slačálek, Ondřej, Eva Svobodová. 2018. "The Czech Islamophobic movement: beyond 'populism'?” Patterns of Prejudice 52 (5): 479-495.

Strapáčová, Michaela, Vít Hloušek. 2018. Anti-Islamism without Moslems: Cognitive Frames of Czech Antimigrant Politics." Journal of Nationalism, Memory \& Language Politics 12 (1): $1-30$.

Svoboda, Pavel. 2015a. "Je islám součástí evropské identity?" [Is Islam part of European identity?]. Aktuálně.cz, December 2, 2015. http://blog.aktualne.cz/blogy/pavel-svoboda. php?itemid=26415.

Svoboda, Pavel. 2015b. "Neexistuje hodný islám a zlý islám." [There is no good islam and evil islam.] KDU-ČSL, January 8, 2015. https://www.kdu.cz/aktualne/archiv/2015/neexistujehodny-islam-a-zly-islam.

Šimáček, Jaroslav. 2015a. "Fiala hájí plot proti uprchlíkům. Podporuje katastrofu, zlobí se kritici." [Fiala defends fence against refugees. He supports catastrophe, critics complain]. Blesk.cz. Accessed March 19, 2020. https://www.blesk.cz/clanek/zpravy-uprchlickakrize/350065/fiala-haji-plot-proti-uprchlikum-podporuje-katastrofu-zlobi-se-kritici.html.

Šimáček, jaroslav. 2015b. "Hádka v ČT kvůli uprchlíkům. Hejtman Hašek a moderátorka Tvarůžková šli do sebe." [Argument in ČT about refugees, regional council president Hašek and host Tvarůžková verbally attacked each other]. Blesk.cz. Accessed March 30, 2020. https://www.blesk.cz/clanek/zpravy-uprchlicka-krize/340552/hadka-v-ct-kvuli-uprchlikum-hejtman-hasek-a-moderatorka-tvaruzkova-sli-do-sebe.html.

Šlerka, Josef, and Jakub Fiala. 2018. "O sebeprezentaci stránky Islám v ČR nechceme na českém Facebooku." [About self-prezentation of page We do not want Islam in $\check{C} R$ on Czech Facebook]. In Islamofobie po česku: český odpor víci islámu, jeho východiska, projevy, souvislosti, presahy i paradox [Islamophobia in the Czech way: Czech aversion towards Islam, its foundations, manifestations, context, overlaps, as well as paradoxes], edited by Bronislav Ostřanský, 235-47. Prague: Vyšehrad.

Telička, Pavel. 2015. “Náměty pro řešení migrační krize.” [Proposals for solving of the migration crisis]. Telicka.eu, July 1, 2015. https://www.telicka.eu/cs/what-we-stand-for/detail/2. 


\section{Journal of Nationalism, Memory \& Language Politics 14(2)}

Tkaczyk, Michal, Pavel Pospěch, and Jakub Macek. 2015. “Analýza mediálního pokrytí uprchlické krize (výzkuná zpráva)." [Analysis of the media coverage of the refugee crisis (technical report)]. Masaryk University 1-6.

Tkaczyk, Michal. 2017. "Between politicization and securitization: coverage of the European migration crisis in Czech online news media." Communication Today 8 (2): 90-110.

TOP09. 2015. “Langšídlová: Být v EU a NATO je pro nás životně důležité.” [Langšádlová: to be in EU and NATO is vitally important for us]. TOP09, August 24, 2015. https://www. top09.cz/co-delame/medialni-vystupy/langsadlova-byt-v-eu-a-nato-je-pro-nas-zivotnedulezite-18777.html.

Vultee, Fred. 2011. "Securitization as a media frame: what happens when the media 'speak security'." In Securitization Theory: How security problems emerge and dissolve, edited by Thierry Balzacq, 77-93. Abingdon: Routledge.

Vuori, Juha A. 2011. "Religion bites: Falungong, securitization/desecuritization in the People's Republic of China." In Securitization Theory: How security problems emerge and dissolve, edited by Thierry Balzacq, 186-211. Abingdon: Routledge.

Warrington, Anna. 2017. "Countering violent extremism via de-securitization on Twitter." Journal for Deradicalization, (11): 258-280.

Zvada, Lubomír. 2018. "Securitization of the Migration Crisis and Islamophobic Rhetoric: The 2016 Slovak Parliamentary Elections as a Case Study." Journal of Nationalism, Memory \& Language Politics 12 (2): 216-235.

Žúborová, Viera, Ingrid Borárosová. 2017. "Migration Discourse in Slovak Politics. Context and Content of Migration in Political Discourse: European Values versus Campaign Rhetoric." Journal of Nationalism, Memory \& Language Politics 11 (1): 1-19.

Mgr. Zbyněk Vallo is a Ph.D. student at the Department of Politics and European Studies at Palacký University Olomouc, focusing primarily on the Middle East and Russian Federation.

Mgr. Robert Jaworek is a Ph.D. student at the Department of General Linguistics at Palacký University Olomouc, focusing primarily on the data analysis in linguistics and on Twitter.

Mgr. Vladimír Matlach, Ph.D. is an Assistant Professor at the Department of General Linguistics at Palacký University Olomouc, focusing on the theory of communication, quantitative analysis of a text, and quantitative linguistics software. 